\title{
Morphology and Function of Gill Mitochondria-Rich Cells in Fish Acclimated to Different Environments
}

\author{
Il-Chi Chang' \\ Tsung-Han Lee $^{2}$ \\ Chi-Hwa Yang ${ }^{3}$ \\ Yuan-Yaw Wei ${ }^{4}$ \\ Fong-In $\mathrm{Chou}^{4}$ \\ Pung-Pung Hwang, ${ }^{3, *}$ \\ 'Institute of Fisheries Science, National Taiwan University, \\ Taipei, Taiwan, Republic of China; 'Department of Zoology, \\ National Chung-Hsing University, Taichung, Taiwan, \\ Republic of China; ${ }^{3}$ Institute of Zoology, Academia Sinica, \\ Taipei, Taiwan, Republic of China; ${ }^{4}$ Nuclear Science and \\ Technology Development Center, National Tsing Hua \\ University, Hsinchu, Taiwan, Republic of China
}

Accepted 9/8/00

\begin{abstract}
The objective of this study is to test the hypothesis that morphologically different mitochondria-rich (MR) cells may be responsible for the uptake of different ions in freshwater-adapted fish. Tilapia (Oreochromis mossambicus) were acclimated to high-Ca, mid-Ca, low-Ca, and low- $\mathrm{NaCl}$ artificial freshwater, respectively, for $2 \mathrm{wk}$. Cell densities of wavy-convex, shallowbasin, and deep-hole types of gill MR cells as well as wholebody $\mathrm{Ca}^{2+}, \mathrm{Na}^{+}$, and $\mathrm{Cl}^{-}$influxes were measured. Low-Ca fish developed more shallow-basin MR cells in the gills and a higher $\mathrm{Ca}^{2+}$ influx than those acclimated to other media. However, fish acclimated to low- $\mathrm{NaCl}$ artificial freshwater predominantly developed wavy-convex cells, and this was accompanied by the highest $\mathrm{Na}^{+}$and $\mathrm{Cl}^{-}$influxes. Relative abundance of shallowbasin and wavy-convex MR cells appear to be associated with changes in $\mathrm{Ca}^{2+}$ and $\mathrm{Na}^{+} / \mathrm{Cl}^{-}$influxes, suggesting that shallowbasin and wavy-convex MR cells are mainly responsible for the uptake of $\mathrm{Ca}^{2+}$ and $\mathrm{Na}^{+} / \mathrm{Cl}^{-}$, respectively.
\end{abstract}

\section{Introduction}

Mammalian collecting duct, amphibian skin, and fish gill are useful models to study the mechanisms of transepithelial trans-

\footnotetext{
*Corresponding author; e-mail: zophwang@ccvax.sinica.edu.tw.
}

Physiological and Biochemical Zoology 74(1):111-119.2001. 2001 by The University of Chicago. Alt rights reserved. 1522-2152/2001/7401-0035\$03.00 port of ions. Intercalated cells in mammalian collecting duct and mitochondria-rich (MR) cells in amphibian skin and fish gills share similar characteristics in morphology and function and, thus, are the target cells for studies on ion transporting cells.

For a long time, studying how these cells perform the transport functions of different ions has been an important and interesting topic. On the basis of the differential expressions of band 3 and vacuolar $\mathrm{H}^{+}$-ATPase, two types, $\alpha$ (or A) and $\beta$ (or B), of intercalated cells in the mammalian collecting duct were identified (Alper et al. 1989). Moreover, the two types of cells were demonstrated to be responsible for the transport of bicarbonates and protons, respectively (Madsen and Tischer 1986; Schuster and Stokes 1987). In amphibian skin, different subtypes or subpopulations of MR cells have also been identified on the basis of functional performances (Larsen 1991; Rick 1992) or cytochemical patterns (Katz et al. 1997). However, evident linkages between morphology and function of different types of MR cells are not yet well established.

The branchial MR cell in fish is another good model system to elucidate the relations of morphologies and functions of transepithelial cells. Teleosts inhabit environments ranging from hypotonic to hypertonic water. Gills are the most important extrarenal organs responsible for ion regulation in teleosts, and the gill MR cells have been demonstrated to play major roles in ionic exchanges by actively excreting or absorbing salts in hyper- or hypotonic milieus, respectively (Epstein et al. 1980; Foskett and Scheffey 1982; Perry 1997). Evident changes in morphology in gill MR cells and in ion regulation have been well documented in teleosts on their acclimation to environments with different osmolarities or ion compositions (Hwang 1987, 1988). Using the vibrating probe technique, Foskett and Scheffey (1982) provided definitive evidence for the location of active $\mathrm{Cl}^{-}$secretion. Moreover, many morphological, biochemical, and physiological studies support the current model (Silva et al. 1977) for salt secretion of MR cells (Epstein et al. 1980; Hwang 1987; Hwang et al. 1988, 1989; Laurent and Perry 1991; Zadunaisky 1984). However, in hypotonic environments, the ion-uptake function ascribed to MR cells is still a matter of discussion (Perry 1997). Uptake of diverse ions, that is, $\mathrm{Na}^{+}$, $\mathrm{Cl}^{-}$, and $\mathrm{Ca}^{2+}$, was shown to correlate significantly with the fractional area of exposed MR cells on the gill filament epithelium of some teleosts, which were treated with hormones or acid/base disturbances (Perry et al. 1992a, 1992b; Bindon et al. 1994). These phenotypic changes were suggested to be a crucial mechanism for ionic (Pisam et al. 1995) or acid-base 
Table 1: lonic compositions ( $\mathrm{mM}$ ) in the artificial freshwater

\begin{tabular}{llllll}
\hline Medium & {$\left[\mathrm{Na}^{+}\right]$} & {$\left[\mathrm{Cl}^{-}\right]$} & {$\left[\mathrm{Ca}^{+2}\right]$} & {$\left[\mathrm{K}^{+}\right]$} & {$\left[\mathrm{Mg}^{2+}\right]$} \\
\hline Low Ca & $.529 \pm .108$ & $.303 \pm .067$ & $.004 \pm .001$ & $.198 \pm .027$ & $.135 \pm .035$ \\
Mid-Ca & $.547 \pm .104$ & $.308 \pm .074$ & $.148 \pm .027$ & $.194 \pm .030$ & $.166 \pm .016$ \\
High Ca & $.807 \pm .199$ & $.321 \pm .077$ & $9.493 \pm 1.96$ & $.199 \pm .029$ & $.161 \pm .022$ \\
Low NaCl & $.017 \pm .008$ & $.023 \pm .02$ & $.151 \pm .021$ & $.189 \pm .028$ & $.167 \pm .016$ \\
\hline
\end{tabular}

Note. Mean $\pm \mathrm{SD}(N=7)$ is indicated.

regulation (Goss et al. 1992). However, the relationships between uptake of diverse ions and phenotypic changes of MR cells are still uncertain up to now. In the past, Wendelaar Bonga and van der Meij (1989) described MR cells as pleomorphic. Pisam et al. (1987) also showed that at least two types of MR cells, $\alpha$ cells and $\beta$ cells, existed in the gill epithelium of freshwater teleosts. Thus, based on this information, we proposed that subpopulations of MR cells with their own function and morphology may exist in the gill epithelium of the teleosts to deal with diverse ionic changes in varied hypotonic milieus. Our previous studies (Lee et al. 1996a, 1996b) have indicated that several types of MR cells with different morphologies in apical crypts exist in fish gills; the densities of these cells are associated with the ionic compositions of environments to which fish were acclimated. However, there is no physiological data to demonstrate that these morphologically different MR cells are responsible for the transport of different ions.

In this study, tilapia (Oreochromis mossambicus) were acclimated to artificial freshwater containing different ionic compositions, and the densities of different types of gill MR cells and ion influxes of $\mathrm{Ca}^{2+}, \mathrm{Na}^{+}$, and $\mathrm{Cl}^{-}$then were measured. The results indicate that the relative densities of different types of MR cells are closely associated with the changes in influxes of $\mathrm{Ca}^{2+}, \mathrm{Na}^{+}$, and $\mathrm{Cl}^{-}$, suggesting that these cells with different morphologies are responsible for the uptake of different ions.

\section{Material and Methods}

\section{Animals}

Male or female tilapia (Oreochromis mossambicus) of $0.3-0.7 \mathrm{~g}$ (for ion flux measurements) and 4.4-12.3 $\mathrm{g}$ (for gill morphology) body weights were obtained from laboratory stocks. The group of small-size fish was used in the ion-influx experiments to decrease the volume of waste isotopic media. The large-size group was used for morphological observations because of convenience in sample preparation. Preliminary studies have confirmed that no significant differences in both morphology and ion influxes were found between these two groups of tilapia. All individuals were reared in aerated local tap water at $26^{\circ}-28^{\circ} \mathrm{C}$ with a photoperiod of $12 \mathrm{~L}: 12 \mathrm{D}$ before the acdimation experiments.

\section{Acclimation Experiments}

Four kinds of artificial freshwater, high $\mathrm{Ca}$, mid-Ca, low $\mathrm{Ca}$, and low $\mathrm{NaCl}$, were prepared by adding appropriate amounts of $\mathrm{NaCl}, \mathrm{MgSO}_{4}, \mathrm{~K}_{2} \mathrm{HPO}_{4}, \mathrm{KH}_{2} \mathrm{PO}_{4}$, and $\mathrm{CaSO}_{4}$ to doubledeionized water (Milli-RO60, Millipore). The ion concentrations of mid-Ca were near the ranges of local freshwater. The ionic compositions (Table 1) of the four media were confirmed by measuring the $\mathrm{Na}^{+}, \mathrm{K}^{+}, \mathrm{Ca}^{2}$, and $\mathrm{Mg}^{2+}$ concentrations with an atomic absorption spectrophotometer (Hitachi Z-8000, Tokyo) and measuring $\mathrm{Cl}^{-}$with a spectrophotometer (Hitachi U2000, Tokyo). The $\mathrm{pH}$ of the media was kept between 6.2 and 6.7 , and the water temperature was $26^{\circ}-28^{\circ} \mathrm{C}$. Tilapia were acclimated to the low- $\mathrm{Ca}$, mid- $\mathrm{Ca}$, high- $\mathrm{Ca}$, and low- $\mathrm{NaCl}$ media for 2 wk and then were sampled for morphological observation (five individuals for each test) and ion influx measurements (four to eight individuals for each test). The acclimation experiment was repeated two to three times. To maintain the water quality, the acclimation media were aerated with a filtered air pump, and the artificial freshwater was prepared and changed every $2 \mathrm{~d}$. The fish were fed with commercial pellets $1 \mathrm{~h}$ before the water change every $2 \mathrm{~d}$, but feeding was stopped $3 \mathrm{~d}$ before the sampling.

\section{Morphology of Gill MR Cells}

After anesthetization with MS222, five fish from each medium were killed to excise the gills. The first gill arch from each side was fixed at $4{ }^{\circ} \mathrm{C}$ in fixative consisting of $5 \%$ glutaraldehyde and $4 \%$ paraformaldehyde in $0.2 \mathrm{M}$ phosphate buffer ( $\mathrm{PB} ; \mathrm{pH}$ 7.2) for $12 \mathrm{~h}$. After rinsing with $0.1 \mathrm{MPB}$, the specimens were postfixed with $1 \%$ osmium tetroxide in $0.2 \mathrm{M} \mathrm{PB}$ for another $1 \mathrm{~h}$. After rinsing with $\mathrm{PB}$ and dehydration with ethanol and acetone, the specimens were infiltrated and embedded in LRwhite resin. Ultrathin sections were cut with glass or diamond knives in an ultramicrotome (Ultracut E, Reichert-Jung, Vienna). Sections were mounted on formvar-coated copper grids, double stained in uranyl acetate and lead citrate, and examined with a transmission electron microscope (TEM; Hitachi, H7000 , Tokyo) at $75 \mathrm{kV}$. For scanning electron microscopy, dehydrated specimens were critical-point dried using liquid $\mathrm{CO}_{2}$ in a critical-point drier (Hitachi HCP-2, Tokyo) and sputter coated for $3 \mathrm{~min}$ with a gold-palladium complex in a vacuum evaporator (Eiko 1B-2, Tokyo). The coated specimens were 
examined in a scanning electron microscope (SEM; Hitachi S2500 , Tokyo) at an accelerating voltage of $15 \mathrm{kV}$.

It has been confirmed previously that in tilapia gill, MR cells were concentrated on the afferent and interlamellar regions of the filament, but no MR cell was found on the efferent flamental surface and the lamellae (Lee et al. 1996a, $1996 b$ ). Densities of different types of MR cells were measured according to Lee et al. $(1996 a, 1996 b)$. The numbers of different types of MR cells among different acclimation media were analyzed by one-way ANOVA. Areas on the afferent side of the filament near the lamellae were chosen at random for counting at $1250 \times$ magnification to measure the densities of different types of MR cells. Three areas $\left(48 \times 84 \mu \mathrm{m}^{2}=\right.$ $4,032 \mu \mathrm{m}^{2}$ each) were counted on each of six gill filaments from a fish. An average of these 18 areas was obtained. Five individuals per group were examined.

\section{Ion Influxes}

Whole-body $\mathrm{Na}^{+}, \mathrm{Ca}^{2+}$, and $\mathrm{Cl}^{-}$influxes were measured following Wood (1992) with some modifications. Tracer media were prepared by adding appropriate amounts of ${ }^{24} \mathrm{NaHCO}_{3}$ (prepared by 1-mW Tsing Hwa Open-Pool Reactor, Nuclear Science and Technology Development Center, National Tsing Hua University, Hsinchu, Taiwan), ${ }^{45} \mathrm{Ca}^{2-}$ (Amersham, Pisca-

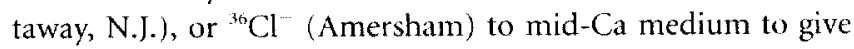
a final working specific activity: ${ }^{24} \mathrm{Na}^{+}, 20,000-36,000 \mathrm{cpm}$ $\mu \mathrm{mol}^{-1} ;{ }^{45} \mathrm{Ca}^{2+}, \quad 510,000-540,000 \quad \mathrm{cpm} \quad \mu \mathrm{mol}^{-1} ;{ }^{36} \mathrm{Cl}^{-}$, 210,000-260,000 $\mathrm{cpm} \mu \mathrm{mol}^{-1}$. After rinsing briefly with mid$\mathrm{Ca}$ water, four (for ${ }^{36} \mathrm{Cl}^{-}$or ${ }^{24} \mathrm{Na}^{+}$) or eight (for ${ }^{45} \mathrm{Ca}^{2+}$ ) fish from each acclimation media were transferred to plastic flux chambers with $20 \mathrm{~mL}$ tracer media for $2.5 \mathrm{~h}$. The tracer media in flux chambers were gently aerated, and the water qualities were confirmed to show no significant change during the period of incubation. The plot of accumulated radioisotope against time was linear within the first $6 \mathrm{~b}(R=0.974 ; N=6$; sampling time: $1,2,3,4,5$, and $6 \mathrm{~h}$ ), and the calculated influxes at each period of the first $6 \mathrm{~h}$ were constant. Moreover, preliminary experiments with fish overanaesthetized on ice indicated that radioisotope sticking to the surfaces of flux chamber and fish was $<2 \%$ of the total radioisotope in the chamber and that the sticking saturated within the first $10 \mathrm{~min}$ of incubation $(N=5$; sampling time: $0,10,20,30,60$, and $150 \mathrm{~min})$. Therefore, water samples ( $100 \mu \mathrm{L}$; three samples for each determination) were collected 0.5 and $2.5 \mathrm{~h}$ after incubation to exclude the effects of sticking. Water samples from the ${ }^{24} \mathrm{Na}^{+}$media were counted for radioactivities with an auto- $\gamma$ counter (B5002, Packard, Meriden, Conn.). Counting solution (Fluoran-safe Scintran, $\mathrm{BDH}$, Poole) was added to water samples from the ${ }^{45} \mathrm{Ca}^{2+}$ or ${ }^{36} \mathrm{Cl}^{-}$media, and then radioactivities were counted with a $\beta$ counter (LS6500, Beckman, Fullerton, Calif.). Volumes of the tracer media were measured at 0.5 and $2.5 \mathrm{~h}$ after incubation. The ion compositions of the tracer media followed those of mid-Ca medium $\left(\left[\mathrm{Ca}^{2+}\right]=0.148,\left[\mathrm{Na}^{+}\right]=0.547\right.$, and $[\mathrm{Cl}]=0.308 \mathrm{mM}$; see above). The ion influxes in fish from different acclimation media were measured in the same levels of ions to compare the ion uptake capacities, although these data did not reflect the actual ion influxes that would occur in the acclimation media.

$\mathrm{Ca}^{2+}, \mathrm{Na}$, or $\mathrm{Cl}^{-}$influx was calculated by the following formula:

$$
J_{i}=\frac{\left(Q_{i} V_{i}-Q_{i} V_{\mathrm{f}}\right)}{\left|1 / 2\left(S A_{i}+S A_{i}\right) t W\right|}
$$

where $Q_{i}$ and $Q_{f}\left(\mathrm{cpm} \mathrm{mL} \mathrm{m}^{-1}\right)$ refer to initial $(0.5 \mathrm{~h})$ and final $(2.5 \mathrm{~h})$ radioactivities in the tracer media, $V_{\mathrm{i}}$ and $V_{\mathrm{f}}(\mathrm{mL})$ refer to initial and final volumes of the tracer media, $S A_{\mathrm{i}}$ and $S A_{\mathrm{f}}$ are initial and fonal specific activities $\left(\mathrm{cpm} \mu \mathrm{mol}^{-1}\right), t(2 \mathrm{~h})$ is incubation time, and $W(\mathrm{~g})$ is body weight of fish. The decay of ${ }^{24} \mathrm{Na}$ during influx experiments was corrected. As all water samples were in the same condition, the effects of quenching on data were excluded through calculation.

\section{Statistical Methods}

All values are presented as means $\pm \mathrm{SE}(N)$. The significance of difference between treatments was assessed by one-way ANOVA (Tukey's pairwise comparison).

\section{Results}

\section{Gill MR cells}

MR cells with different morphologies of apical surfaces-deep hole, shallow basin, and wavy convex-were observed on the afferent side of gill filaments (Fig. 1). As Lee et al. (1996a, $1996 \mathrm{~b}$ ) reported, the morphologies of apical membranes of different types of MR cells, which were examined with the TEM (Fig. 1), reflected what was observed under the SEM (Fig. 2). With larger size of dimension, the apical membranes of the wavy-convex MR cells gave a convex surface appearance. The ovoid apertures of shallow-basin MR cells with medium size in dimension were occasionally ornamented with short microvilli. The deep-holed MR cells with smaller size in apical dimension were narrow, deep, round-to-oval pores in which little or no internal structure was visible.

Low-NaCl groups developed more MR cells (total number $=5.62 \pm 0.60$ cells per unit area of filament) than other groups (low Ca, $3.34 \pm 0.55$; mid-Ca, $3.26 \pm 0.40$; high $\mathrm{Ca}, 2.96 \pm 0.56)$. However, dramatic changes were found in the compositions of the three types of gill MR cells among the different groups of tilapia (Figs. 2, 3, 4). Both high-Ca and low- $\mathrm{NaCl}$ groups dominantly developed wavy-convex MR cells, while shallow-basin MR cells dominated in the mid-Ca and low-Ca groups. Among the four groups, low-NaCl tilapia was the highest in both cell density and relative density of wavy- 

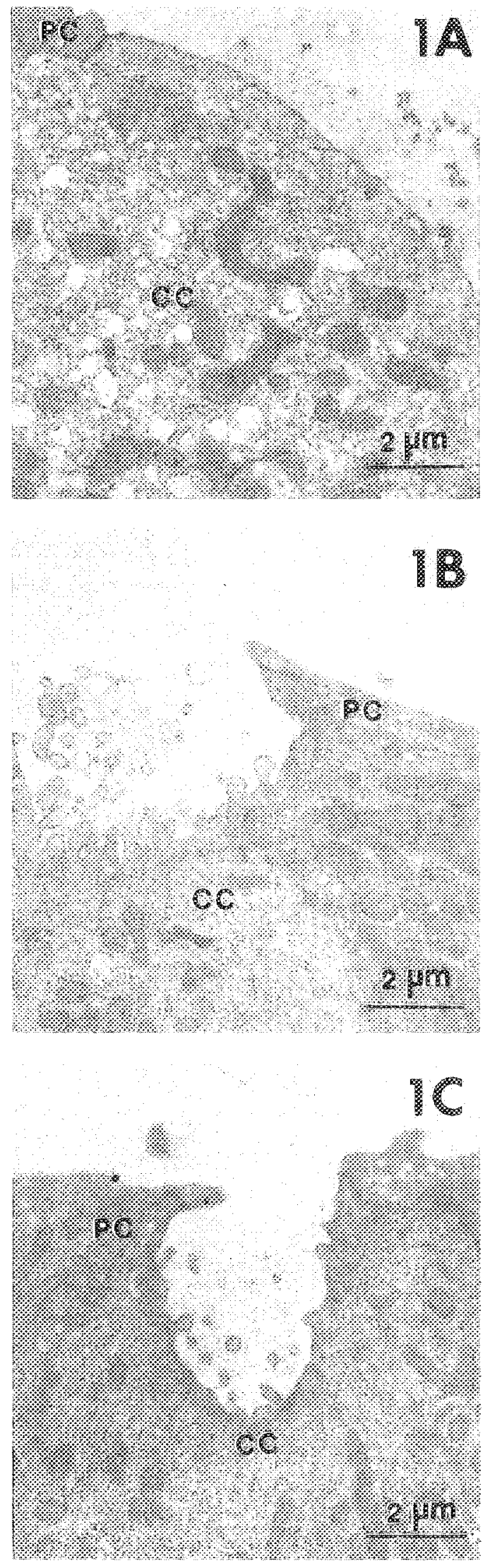

convex cels, while low-Ga fish showed the highest walue in both parameters of shallow basin cells. With regard to deepholo type of MR cells, no signiffant diferences were found in cell densivy among the four groups of tilapia. These results indiate that declining environmental $\mathrm{Ca}^{2}$ concentrations stimulate the development of shallow-basin-type MR cells; in contrast, high environmental $\mathrm{Ca}^{2}$ or low environmental $\mathrm{NaCl}$ levels whance the development of wavy-convex-type MR cells in tilapia gills.

\section{Ga" Infhx}

Cat influxes in tilapia acchmated to different artificial media; low Ca, mid-Ca, high Ca, and low NaCI were compared, and the results indicate significant differences among the four groups (Fig. 5 A one-way ANOVA, Tukey's parwise comparison). Low-Ca tilapia showed a signifenty higher $\mathrm{Ca}^{2}$ influx that was about 1.3-1.9-10ld higher than that of other groups (Fig. 5A). Moreover, environmental Cat levels induced a concentration-dependent effect on $\mathrm{Cat}^{2}$ influx in tilapia based on the data of low-Ca, mid Cand high Ca groups (Tig. 5A). No signifcand difference was foun between high-Ca and low-NaCh groups (Fig. 5A). These results indicate that declining environmental $\mathrm{Ca}^{2+}$ levels stmulate $\mathrm{Ca}^{2+}$ influx in tilapia.

\section{Na Inhx $_{4}$}

Significant differences in the $\mathrm{Nat}$ influxes were also found among the four groups (Fig. $5 B$; one-way ANOVA, Tukey's parwise comparison). Na influxes of bow-NaCl groups were signiffantly higher than those of high-Ca, low $\mathrm{Ca}$, and midCa groups (Kg 5 B). Low NaCl thapia reveled the highest $\mathrm{Na}^{4}$ influs, about $3.4,3.3$, and 1.8 thmes those of low-Ca, mid-Ca, and high-Ca tilapia, respetively.

\section{Cl $\ln h \ln x$}

Similat to the data of $\mathrm{Ca}^{2+}$ and $\mathrm{Aa}$ intuxes as describec above, significant differences in $\mathrm{Cl}$ intuxes were found among the four groups (Fig. 5C; one-way ANOVA, Tukey's peirwise comparison). Mid-Ca tilapia showed a significantly lower level of Cl infux than those of the low-Ca, high-Ca, snd low- $\mathrm{NaCl}$ groups. Low- NaCl thpia revealed a $\mathrm{Cl}$ infux about 1.7 times higher than those of mid Ca tiapia, indicating the effect of envimonental $\mathrm{Na}^{+} / \mathrm{Cl}$ levels on $\mathrm{C}$ indux in tilapia (Hg. $5 \mathrm{C}$ ).

Higure 1. THM images of branchial MR cels with different apical morphologies in freshwater tilapia. $A$, Wavy convex MR cell; $B$, shallow-basin Mr cell; $C$ dephole $M R$ cell $C O=M R$ cell; $P C=$ pavement cell. Magnification, $7,000 \times$. 

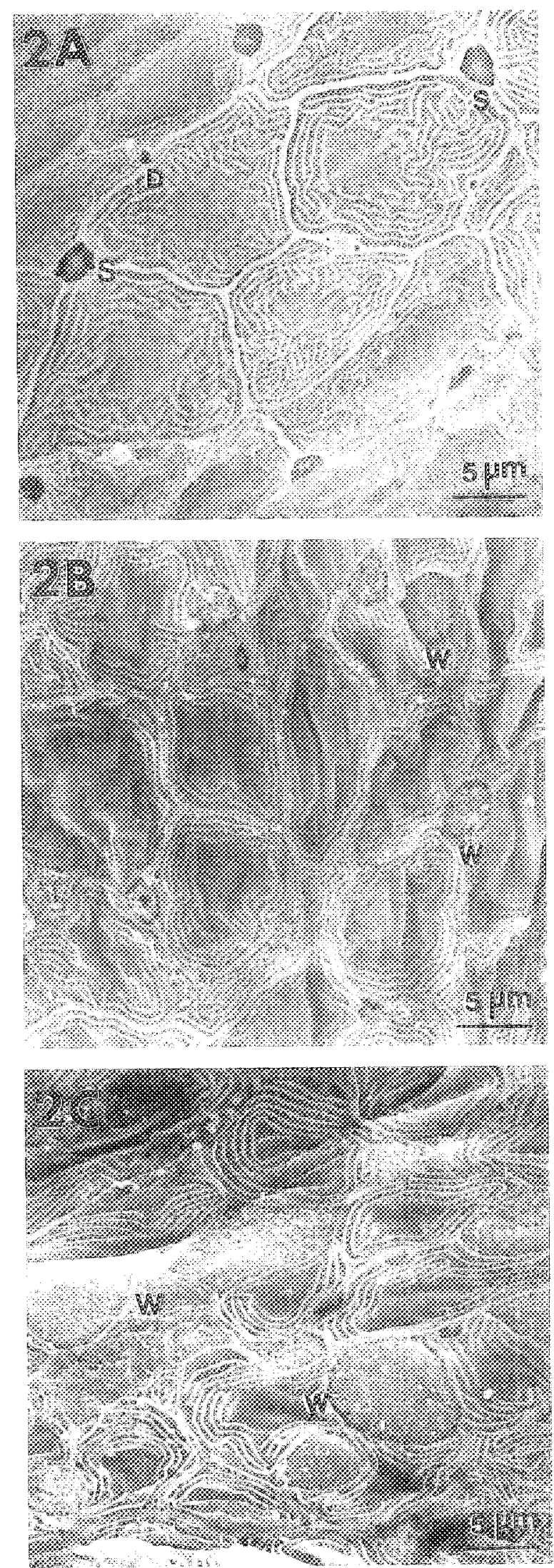

\section{Duchssion}

According to cell shaps, whrastructure, and localization in gills wher TEM, wo distinguishable MR cell types, $\alpha$ and $\beta$, have been identifed (Pisam at. 1987). In this study, three MR cell types, shalow basin, deep hole, ant way convex (Lee et al. 1996b), were used to describe nodification in apical surface of MR cell wenter SEM. According to amounts of apical cabohybrates or cell density in low-Ca arsifcial freshwater, Tsai and Hwang (1998b) moposed that WGA-positive (WGA = wheat gem agghtinin, one kind of lechin that can bind with carbotydrates) MR cels (apical carbolydrates rich) are considered to be similar to $\beta \mathrm{MR}$ cells whose apical region is rich in carbohydrates (Pismet al 1995) ot to shallow-basin-type MR cells that are the dominant MR cell type in low-Cat artifcial

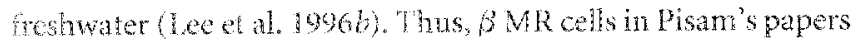
look like shallow-basin MR cells. Moreover, in seawateradapred tilapid, there is only one iype of MR cells, which were ranted $\alpha$ MR cells (Bisam et al. 1987) or deep-hole MR cels (Lee at. 19966,2000 ). Herce, Pisam's $\alpha$ MR cells should be ceophole Mx cells in mur sudy. Meambile, there is no nor phological description in pisan's studies similar to the wavyconvex-type MR cols in our prewious study (tee et al. 1996b). However, no direct evidence is avalable to elucidate this possinnle linkage in these two MR cell clasifications. Methods (SEM and $(E M)$ or media for acdmation are perhaps the causes for the difference in these wo Mro cell classifications.

There is no direct evidence to confin the different function of $\alpha$ ard $\beta M R$ cells. On the basis of extensive studies examining the chects onviromental salinites or jon levels and exog. crous bomones on the apperance of $\alpha$ and $\beta$ MR cels (Pisam At al. 1993), it was suggented that $\beta$ MR cells may be associated with Cat" upkake, while a MK cells exert dual functions: $\mathrm{Cl}$ secretion in salt water and $\mathrm{Nat}$ uptake in freshwater (Pisam et al. 1993, 1995$)$. However, no influx data are avallable to support their inference, and the functons of $\alpha$ and $\beta$ MR cells in freshwater are still a matter of bisclswion (Perry 1997). Perry (1997) suggested that physiologion significance of the different MR cell types needed to be proved. According to varability in the surface ared of exposes MRe cels on the gill epithelia in cortisoltreared fish, it was stggested that MR cells are involved in $\mathrm{Ca}^{2}$ and $\mathrm{Na}$ or Cl buke (Pery et al. 1992a, 1992b). Conversely, Goss of al (1992) suggested that ol infux and $\mathrm{Na}^{+}$influx changed with exposed area of MR cels and pavement cells, respetively, during hyperponic acidasis. These studies ind coted that MR cells are the sice for $\mathrm{an}^{2-4}$ and Cl uptake, while

Higure 2. SHM images of the apical mophologies of branctial MR cell in tilapia acdimated to deforent media, Shallow-basin MR cells (S) were prebonimant in low Ca (4), while wavy-convex MR cells (W) were predominant in bigh $C a(B)$ and low $N a(C) \cdot C=$ decp-bole MR colis. Magnification, $2,200 \times$. 


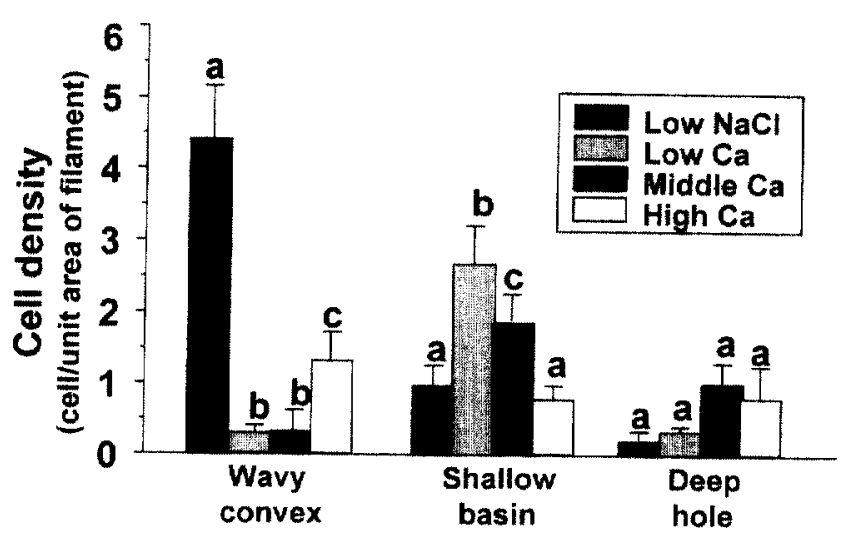

Different types of MR cells

Figure 3. Densities of different types of gill MR cells in tilapia acclimated to different media. Means $\pm \mathrm{SE}(N=5)$ is shown. One-way ANOVA was conducted among different media for each type of MR cell, and different letters indicate significant differences between different media (Tukey's pairwise comparison). Unit area of filament was described in "Material and Methods."

pavement cells are responsible for $\mathrm{Na}^{-+}$uptake. However, these authors never distinguished gill MR cells with different morphologies, nor did they provide any correlated data between different MR cell types and the uptake of various ions. In this study, artificial freshwater media with various ionic compositions were used to stimulate the influxes of various ions and the development of different types of gill MR cells, and the correlated results suggested that the morphological alternation of gill MR cells reflect their ionic demand.

Previously, we identified wavy-convex, shallow-basin, and deep-hole MR cells based on the apical morphology under SEM observations and found a close association between the relative densities of these cells and environmental ion $\left(\mathrm{Na}^{+}, \mathrm{Cl}^{-}\right.$, and $\mathrm{Ca}^{2+}$ ) compositions (Lee et al. 1996a, 1996b). Therefore, we proposed the functions of $\mathrm{NaCl}$ uptake and $\mathrm{Ca}^{2+}$ uptake for wavy-convex and shallow-basin MR cells, respectively. These results provide direct influx data to support our hypothesis. These artificial freshwater media (low $\mathrm{Ca}$, mid-Ca, high $\mathrm{Ca}$, and low $\mathrm{NaCl}$ ) differ in concentrations of $\mathrm{Na}^{+}, \mathrm{Cl}^{-}$, and $\mathrm{Ca}^{2+}$, and thus, this experimental protocol enabled us to identify more clearly the relation between ion fluxes and the dominant types of MR cells. Decreasing environmental $\mathrm{Ca}^{2+}$ appears to stimulate the $\mathrm{Ca}^{2+}$ influx and the occurrence of shallow-basin type of MR cells, while decreasing environmental $\mathrm{NaCl}$ enhances $\mathrm{Na}^{+}$and $\mathrm{Cl}^{-}$influxes as well as the occurrence of wavyconvex-type MR cells.

Previous studies have suggested the effects of environmental $\left[\mathrm{Ca}^{2+}\right]$ on the permeability of other ions such as $\mathrm{Na}^{+}$and $\mathrm{Cl}^{-}$ (Avella et al. 1987). When we carefully compared the ion compositions of the artificial media, densities of MR cells, and influxes of ions, complicated interactions between ions were also found. The low $\mathrm{NaCl}$ has the same environmental $\left[\mathrm{Ca}^{2+}\right]$ as the mid-Ca group, yet there were significantly fewer shallowbasin cells and lower $\mathrm{Ca}^{2+}$ influx in the former groups (Table l; Figs. 2-5), suggesting a possible effect of environmental $\left[\mathrm{Na}^{+} / \mathrm{Cl}^{-}\right]$on $\mathrm{Ca}^{2+}$ balance. The high-Ca, mid-Ca, and low-Ca groups, which have similar environmental $\left[\mathrm{Na}^{+} / \mathrm{Cl}^{-}\right]$, were different in influxes of $\mathrm{Na}^{+}$and $\mathrm{Cl}^{-}$and in densities of wavyconvex cells (Table 1; Figs. 2-5), implying that the effects of environmental $\left[\mathrm{Ca}^{2+}\right]$ on $\mathrm{Na}^{+}$and on $\mathrm{Cl}^{-}$fluxes were different. It is difficult, and not the major objective of this study, to distinguish the interactions among different ions. In this study, artificial freshwater media with various ionic compositions were used as a tool to stimulate the influxes of various ions $\left(\mathrm{Ca}^{+2}\right.$, $\mathrm{Na}^{+}$, and $\mathrm{Cl}^{-}$) and the development of morphologically different MR cells to elucidate the correlation between functions and morphologies of MR cells. Despite the complicated interactions among different ions, these results evidently indicated that positive correlation occurred only between density of wavyconvex cells and influxes of $\left[\mathrm{Na}^{+}\right]$and $\left[\mathrm{Cl}^{-}\right]$(comparison between low- $\mathrm{NaCl}$ and mid-Ca groups) and between shallowbasin cells and $\mathrm{Ca}^{2+}$ influxes (comparison among high-Ca, mid-Ca, and low-Ca groups).

In tilapia (Oreochromis mossambicus) gill, Tsai and Hwang (1998b) identified WGA-positive MR cells based on amounts of apical carbohydrates and suggested that these cells are similar to shallow-basin-type MR cells. When acclimated to low-Ca freshwater $\left(\left[\mathrm{Ca}^{2+}\right]=0.015 \mathrm{mM}\right)$ for $4 \mathrm{~d}$, the number of $\mathrm{WGA}$ positive MR cells increased in tilapia (Tsai and Hwang 1998b). In a subsequent study, Tsai and Hwang (1998a) demonstrated

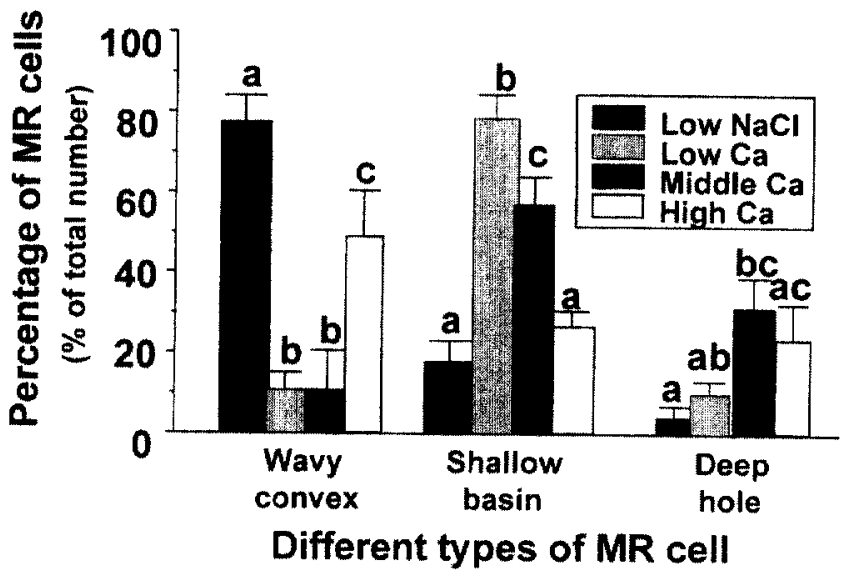

Figure 4. Relative abundance of different types of gill MR cells in tilapia acclimated to different media. Means $\pm \mathrm{SE}(N=5)$ is shown. Oneway ANOVA was conducted among different media for each type of MR cell, and different letters indicate significant differences between different media (Tukey's pairwise comparison). 

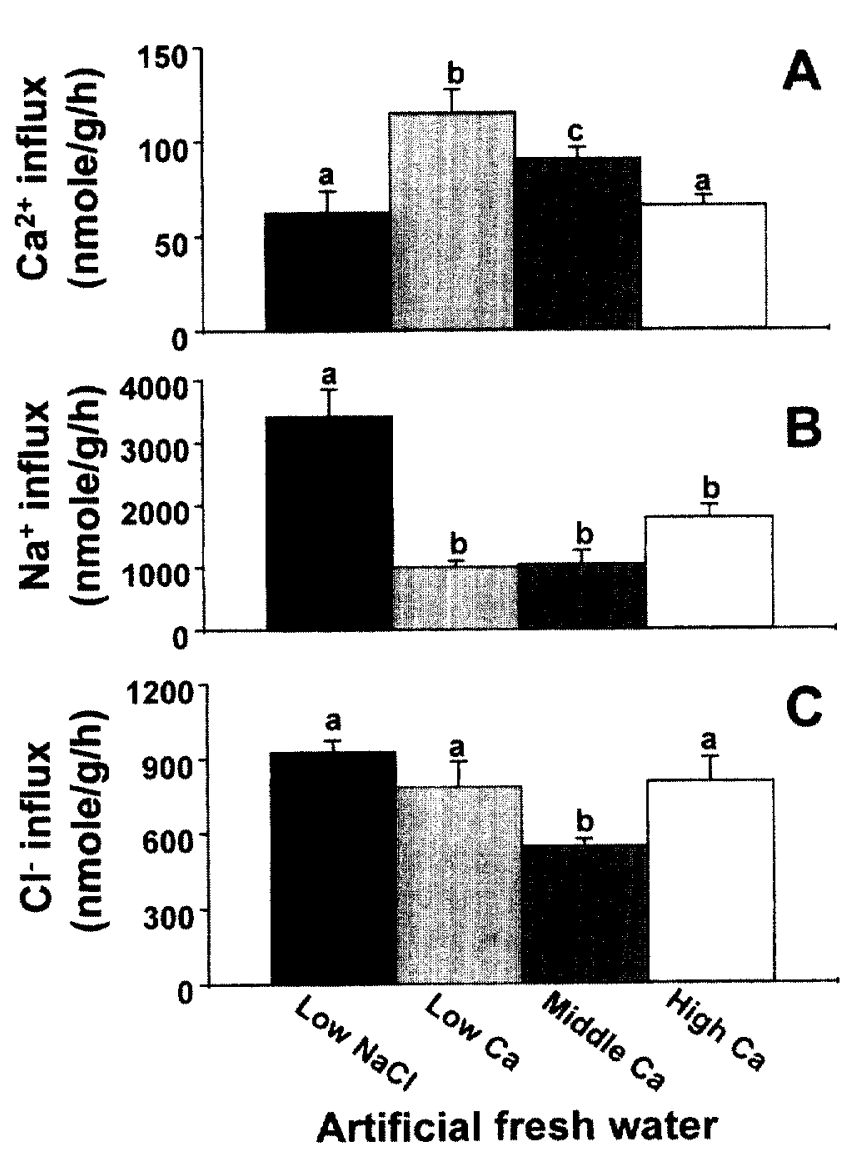

Figure 5. $\mathrm{Ca}^{2+}(A), \mathrm{Na}^{+}(B)$, and $\mathrm{Cl}^{-}(C)$ influxes in tilapia acclimated to different media. Means $\pm S E\left(N=8,4\right.$, and 4 for $\mathrm{Ca}^{2+}, \mathrm{Na}^{1}$, and $\mathrm{Cl}^{*}$, respectively) are shown. One-way ANOVA was conducted among different media for each ion influx, and different letters indicate significant differences between different media (Tukey's pairwise comparison).

the association between WGA-binding sites in MR cells and $\mathrm{Ca}^{2+}$ uptake in gills of tilapia, which was suggested to be involved in adjusting the microtubule network. Treatment with WGA concurrently enhanced $\mathrm{Ca}^{2+}$ influx and fluorescence intensity of the microtubules in gill MR cells in tilapia kept in extremely low $\mathrm{Ca}$ freshwater $\left(\left[\mathrm{Ca}^{2+}\right]=0.002 \mathrm{mM}\right.$; Tsai and Hwang 1998a). These findings, while similar to this study, also support the hypothesis about the major function of shallowbasin-type (or WGA-positive) MR cells: that they are associated with $\mathrm{Ca}^{2+}$ uptake in freshwater fish.

MR cells are believed to be the principle site for $\mathrm{Cl}$ uptake, while the role of MR cells in $\mathrm{Na}^{+}$uptake is still being debated. MR cells are suggested to be the major site for $\mathrm{Cl}^{-}$uptake via apical $\mathrm{Cl}^{-} / \mathrm{HCO}_{3}^{-}$exchanger in the model of amphibian skin (Harvey 1992; Klein et al. 1997) and probably also in the model for freshwater-adapted fish gills (Perry 1997). In amphibian skin, the $\mathrm{H}^{4}$-ATPase in MR cells hyperpolarizes the apical membrane and, consequently, facilitates passive electrodiffusion of $\mathrm{Na}^{+}$through $\mathrm{Na}^{+}$channels present in both MR cells and principal cells (another type of epithelial cell in skin; Harvey 1992; Klein et al. 1997). The $\mathrm{Na}^{+}$channels in MR cells provide the major route for $\mathrm{Na}$ absorption when an acid load closes the $\mathrm{Na}$ channels in principal cells (Harvey 1992; Klein et al. 1997). However, some studies have indicated that amilorideinhibitable uptake of $\mathrm{Rb}^{+}$was restricted to principal cells irrespective of the experimental conditions, and $\mathrm{Na}^{+}$uptake across MR cells appears to be negligible (Nagel and Dorge 1996). In gills of freshwater fish, a similar $\mathrm{Na}^{-4}$ absorption mechanism via $\mathrm{H}^{+}$-ATPase and $\mathrm{Na}^{+}$channels was suggested to be restricted mainly to gill pavement cells and not to MR cells (Perry 1997). No correlation was found between MR cell surface area and $\mathrm{Na}^{+}$uptake/acid excretion on acid-base disturbance, and environmental $\mathrm{Na}^{+}$concentrations affected the intracellular $\mathrm{Na}^{+}$levels in pavement cells only (Morgan et al. 1995). However, the data about the localization of $\mathrm{H}^{+}$-ATPase in MR cells or pavement cells are still controversial (Perry 1997). In this study, the correlated data between wavy-convex $\mathrm{MR}$ cell density and influxes of $\mathrm{Na}^{+}$and $\mathrm{Cl}^{-}$could not answer whether the key factor stimulating the occurrence of wavyconvex $\mathrm{MR}$ cells is $\mathrm{Na}^{+}, \mathrm{Cl}$, or both. This is because the environmental $\mathrm{Na}^{+}$and $\mathrm{Cl}^{-}$levels were designed to change in parallel following our previous study (Lee et al. 1996a, 1996b). In a further study, experiments dealing respectively with $\mathrm{Na}^{+}$ or $\mathrm{Cl}^{-}$should be designed to certify whether wavy-convex $\mathrm{MR}$ cells are mainly responsible for the uptake of $\mathrm{Na}^{+}, \mathrm{Cl}^{\prime}$, or both in freshwater-adapted fish.

The function of deep-hole MR cells is not yet clear from this study, as the changes in the densities of deep-hole cells did not show evident positive relation either with the stimulation of $\mathrm{Ca}^{2+}$ uptake or with those of $\mathrm{Na}^{+}$and $\mathrm{Cl}^{-}$. It was suggested that the function of deep-hole MR cells may be associated with the secretion of $\mathrm{Na}^{+}$and/or $\mathrm{Cl}$ because only deep-hole $\mathrm{MR}$ cells were observed in $>5 \%$ seawater treatment (Lee et al. 1996b, 2000). Recently, we found that deep-hole MR cells increased in cell number and the size of apical opening following the increase of salinity to which fish were acclimated (Lee et al. 2000). This implies that deep-hole MR cells appearing in hypotonic freshwater might be in a resting state and preparing to conduct the excretion of $\mathrm{Na}^{+}$and/or $\mathrm{Cl}$ on higher salinity challenges. This needs further study to confirm.

In conclusion, this study provides, for the first time, direct linkage between ion influxes and relative densities of morphologically different MR cells. These data demonstrate multiple functions of morphologically different MR cells; that is, the wavy-convex and shallow-basin types (or subtypes) are responsible mainly for the uptake of $\mathrm{Na}^{+} / \mathrm{Cl}^{-*}$ and $\mathrm{Ca}^{2+}$, respectively, in freshwater-adapted fish. Much remains to be done in the future, such as the quantification and the distribution of the ion transporters. 


\section{Acknowledgments}

This study was supported by grants to P.-P.H. from the National Science Council (NSC 88-2311-B001-066) and Academia Sinica (Major Group-Research Project), Taiwan, Republic of China.

\section{Literature Cited}

Alper S.L., J. Natale, S. Gluck, H.F. Lodish, and D. Brown. 1989. Subtypes of intercalated cells in rat kidney collecting duct defined by antibodies against erythroid band 3 and renal vacuolar $\mathrm{H}^{+}$-ATPase. Proc Natl Acad Sci USA 86:5429-5433.

Avella M., A. Masoni, M. Bornancin, and N. Mayer-Gostan. 1987. Gill morphology and sodium influx in the rainbow trout (Salmo gairdneri) acclimated to artificial freshwater environments. J Exp Zool 241:159-169.

Bindon S.D., K.M. Gilmour, J.C. Fenwick, and S.F. Perry. 1994. The effects of branchial chloride cell proliferation on respiratory function in the rainbow trout, Oncorhynchus mykiss. J Exp Biol 197:47-63.

Epstein F.H., P. Silva, and G. Kormanik. 1980. Role of Na-KATPase in chloride cell function. Am J Physiol 238: R246-R250.

Foskett J.K. and C. Scheffey. 1982. The chloride cell: definitive identification as the salt-secretory cell in teleosts. Science 215 : $164-166$.

Goss G.G., S.F. Perry, C.M. Wood, and P. Laurent. 1992. Mechanisms of ion and acid-base regulation at the gills of freshwater fish. J Exp Zool 263:143-159.

Harvey B.J. 1992. Energization of sodium absorption by the $\mathrm{H}^{+}$-ATPase pump in mitochondria-rich cells of frog skin. J Exp Biol 172:289-309.

Hwang P.-P. 1987. Tolerance and ultrastructural responses of branchial chloride cells to salinity changes in the euryhaline teleost Oreochromis mossambicus. Mar Biol 94:643-649.

1988. Multicellular complex of chloride cells in the gills of freshwater-adapted teleosts. J Morphol 196:15-22.

Hwang P.-P., C.M. Sun, and S.M. Wu. 1988. Characterization of gill $\mathrm{Na}^{+}-\mathrm{K}^{+}$-activated adenosine triphosphatase from tilapia Oreochromis mossambicus. Bull Inst Zool Acad Sin 7: $49-56$.

1989. Changes of plasma osmolality, chloride concentration and gill $\mathrm{Na}-\mathrm{K}$-ATPase activity in tilapia Oreochromis mossambicus during seawater acclimation. Mar Biol 100: 295-299.

Katz U., G. Zaccone, S. Fasulo, A. Mauceri, and S. Gabbay. 1997. Lectin binding pattern and band 3 localization in toad skin epithelium and the effect of salt acclimation. Biol Cell 89:141-152.

Klein U., M. Timme, W. Zeiske, and J. Ehrenfeld. 1997. The $\mathrm{H}^{-}$pump in frog skin (Rana esculenta): identification and localization of a V-ATPase. J Membr Biol 157:117-26.
Larsen E.H. 1991. Chloride transport by high-resistance heterocellular epithelia. Physiol Rev 71:235-283.

Laurent P. and S.F. Perry. 1991. Environmental effects on fish gill morphology. Physiol Zool 53:4-25.

Lee T.H., P.-P. Hwang, and S.H. Feng. 1996a. Morphological studies on gill and mitochondria-rich cells in the stenohaline cyprinid teleosts, Cyprinus carpio and Carassius auratus, adapted to various hypotonic environments. Zool Stud 35: $272-278$.

Lee T.H., P.-P. Hwang, H.C. Lin, and F.L. Huang. $1996 b$. Mitochondria-rich cells in the branchial epithelium of the teleost, Oreochromis mossambicus, acclimated to various hypotonic environments. Fish Physiol Biochem 15:513-523.

Lee T.H., P.-P. Hwang, Y.E. Shieh, and C.H. Lin. 2000. The relationship between "deep-hole" mitochondria-rich cells and salinity adaptation in the euryhaline teleost, Oreochromis mossambicus. Fish Physiol Biochem (in press).

Madsen K.M. and C.C. Tischer. 1986. Structural-functional relationship along the distal nephron. Am J Physiol 250: F1-F15.

Morgan I.J., W.T.W. Potts, and K. Oates. 1995. Intracellular ion concentrations in branchial epithelial cells of brown trout (Salmo trutta) determined by x-ray microanalysis. J Exp Biol 194:139-151.

Nagel W. and A. Dorge. 1996. The role of mitochondria-rich cells in sodium transport across amphibian skin. Pfleug Arch 433:146-152.

Perry S.F. 1997. The chloride cell: structure and function in the gills of freshwater fishes. Annu Rev Physiol 59:325-347.

Perry S.F., G.G. Goss, and J.C. Fenwick. 1992a. Interrelationships between gill chloride cell morphology and calcium uptake in freshwater teleosts. Fish Physiol Biochem 10:327-337.

Perry S.F., G.G. Goss, and P. Laurent. 1992b. The interrelationships between gill chloride cell morphology and ionic uptake in four freshwater teleost. Can J Zool 70:1775-1786.

Pisam M., B. Auperin, P. Prunet, and A. Rambourg. 1993. Effects of prolactin on $\alpha$ and $\beta$ chloride cells in the gill epithelium of the saltwater adapted tilapia Oreochromis niloticus. Anat Rec 235:275-284.

Pisam M., A. Caroff, and A. Rambourg. 1987. Two types of chloride cells in the gill epithelium of a freshwater-adapted euryhaline fish, Lebistes reticulatus: their modification during adaptation to salt water. Am J Anat 179:40-50.

Pisam M., C. LeMoal, B. Auperin, P. Prunet, and A. Rambourg. 1995. Apical structures of "mitochondria-rich" alpha and beta cells in euryhaline fish gill: their behavior in various living conditions. Anat $\operatorname{Rec} 241: 13-24$.

Rick R. 1992. Intracellular ion concentrations in the isolated frog skin epithelium: evidence for different types of mitochondria-rich cells. I Membr Biol 127:227-236.

Schuster V.L. and J.B. Stokes. 1987. Chloride transport by the cortical and outer medullary collecting duct. Am J Physiol 253:F203-212. 
Silva P., R. Solomon, K. Spoke, and F.H. Epistein. 1977. Ouabain inhibition of gill Na-K-ATPase: relationship to active chloride transport. J Exp Zool 99:419-426.

Tsai J.C. and P.-P. Hwang. 1998a. Effects of wheat germ agglutinin and colchicine on microtubules of the mitochondriarich cells and $\mathrm{Ca}^{2+}$ uptake in tilapia (Oreochromis mossambicus) larvae. J Exp Biol 201:2263-2271.

1998b. The wheat germ agglutinin binding sites and development of the mitochondria-rich cells in gills of tilapia (Oreochromis mossambicus). Fish Physiol Biochem 19:95-102.
Wendelaar Bonga S.E. and J.C.A. van der Meij. 1989. Degeneration and death, by apoptosis and necrosis, of the pavement and chloride cells in the gills of the teleost Oreochromis mossambicus. Cell Tissue Res 255:235-243.

Wood C.M. 1992. Flux measurements as indices of $\mathrm{H}^{+}$and metal effects on freshwater fish. Aquat Toxic 22:239-264.

Zadunaisky J.A. 1984. The chloride cell: the active transport of chloride and the paracellular pathways. Pp. 129-176 in W.S. Hoar and D.J. Randall, eds. Fish Physiology. Vol. 10B. Academic Press, Orlando, Fla. 